\title{
Studies on the relation between bladder cancer and benzidine or its derived dyes in Shanghai
}

\author{
You Xue-Yun, Chen Ji-Gang, Hu Yong-Ning
}

\begin{abstract}
Shanghai is the largest industrial centre in China and has a history of about 50 years in producing and applying benzidine derived dyes. A series of epidemiological studies on the carcinogenicity of benzidine and its derived dyes have been performed since 1979. This report describes three such studies. A casecontrol study was carried out on 344 cases of bladder cancer, each matched for age and sex, with a person without bladder cancer. Factors studied were occupational exposure, smoking, drinking, medical histories, and family history of bladder cancer and other carcinomas. The correlation between bladder cancer and occupational exposures (relative risk (RR) 5.71) was greater than that between bladder cancer and smoking (RR 1.53). A retrospective cohort study was conducted in seven dyestuffs factories where benzidine had served as an intermediate in the manufacture of dyes before 1976. The cohort was made up of 550 men and 186 women. The men were divided into two groups according to job; 354 were assigned to a presynthesis group and 196 to a postsynthesis group. Those in the presynthesis group were thought to have been exposed to benzidine and the subjects in the postsynthesis group were exposed mainly to its derived dyes. The 15 cases of bladder cancer diagnosed were all in the presynthesis group, although an excess of bladder cancer was also seen in the whole cohort. The standardised incidence ratio (SIR) of bladder cancer was 1918 in the whole cohort and 3500 in the presynthesis group. Moreover, the SIR of bladder cancer in a subgroup working directly with the assignment, transport, and mixing of benzidine was as high as 7500 . A further retrospective cohort study was made on incidence of cancer among 1420 workers who used benzidine derived dyes in 43 textile printing and dyeing factories. No excess of
\end{abstract}

Department of Occupational Cancer, Shanghai Institute of Industrial Hygiene and Occupational Diseases, Shanghai, People's Republic of China $Y$ Xue-Yun, $C$ Ji-Gang, $H$ Yong-Ning carcinoma was found. These results suggest $\stackrel{\omega}{\circ}$ that, in Shanghai, the main cause of bladder $\mathbb{\mathbb { D }}$ cancer is occupational exposure, especially to 3 benzidine. The risk of bladder cancer, $₫$ however, existed only in the presynthesis stage $\infty$ of dye manufacture.

In the 1970s the incidence of bladder cancer had clearly increased in Shanghai when compared with the 1960s, and there was a tendency towards anc increased risk in the chemical dyestuffs industry. $\stackrel{1}{\sim}$ Evidence existed showing that certain aromatic $\vec{\theta}$ amines were the cause of bladder cancer in man. To. explore the effect of occupational exposure to one of the carcinogenic aromatic amines, benzidine, and its derived dyes on bladder cancer in Shanghai a series of epidemiological investigations were carried out comprising a case-control study on bladder cancer, $a \frac{\Phi}{\Phi}$ retrospective cohort study on bladder cancer among $\Rightarrow$ workers exposed to benzidine in the Shanghai dye-윽 stuffs industry, and a retrospective cohort study on cancers among the users of benzidine derived dyes in Shanghai textile printing and dyeing industries.

Subjects, methods, and results CASE-CONTROL STUDY

A total of 442 cases of bladder cancer, alive on 310 August 1978, were compiled from various parts of Shanghai industry. The cases were matched with of single control, a non-cancer patient diagnosed in the same hospital, of the same sex, and aged within five years of the cases. The controls were also from then same industrial and residential districts as the cases.

The study included a record of histories of smok- $N$ ing and drinking (age of starting, amount a day, and giving up or not), histories of chronic diseases, familyo histories of cancers, occupational histories (recordso of employment), and histories of bladder cancer. AlE workers employed in the dyestuffs, rubber, cable $\stackrel{0}{+}$ ink, dress pressing, and cigarette industries for more $D$ than six months were considered as having a positive occupational exposure.

The investigation was conducted by visiting the cases and controls. Of the 442 original cases, 42 diedoduring the period of investigation, 13 were misdiagnosed, and 53 could not be traced. Thus only 334 
Table 1 Risk of bladder cancer associated with various histories

\begin{tabular}{lll}
\hline History & $R R$ & $p$ Value \\
\hline Occupational exposure & $5 \cdot 71$ & $<0.001$ \\
Smoking & 1.53 & $<0.05$ \\
Drinking & $1 \cdot 21$ & NS \\
Liver disease & 0.88 & NS \\
Stomach disease & 1.07 & NS \\
Tuberculosis, any form & 1.25 & NS \\
Family history of bladder cancer & $1.29^{\star}(5 / 0) \dagger$ & NS \\
Family history of other carcinoma & 1.66 & NS \\
\hline
\end{tabular}

*Comparison of having or not having family history of bladder cancer.

tComparison of having family history of bladder cancer and not having family history of other carcinomas.

$\mathrm{NS}=\mathrm{p}>0.05$.

(317 men and 17 women) remained for analysis. Because of the small number of women, analysis was restricted to the 317 men and their matched controls. Among the 317 cases, 315 had a pathological diagnosis of transitional cell carcinoma; two had the diagnosis proved by endoscopy. The cases were aged 23-78 with a peak of incidence of cancer between 50 and 69.

Table 1 shows the association of bladder cancer with various histories, estimated as relative risk; the Mantal-Haenszel test was used for statistical analyses. Of the eight factors, only the relative risks for occupational exposure and cigarette smoking were statistically significant. After adjustment for occupation or smoking both were still correlated with incidence of bladder cancer: the relation between occupational exposure to benzidine and incidence of bladder cancer was closer than that between smoking and incidence of bladder cancer (table 2).

Table 3 shows the occupations of the 41 cases of bladder cancer with a history of occupational exposure to benzidine. Most had worked directly with benzidine derived dyes.

\section{RETROSPECTIVE COHORT STUDY IN THE DYESTUFFS INDUSTRY}

Benzidine had been used in Shanghai since 1946, but in 1976 its use was prohibited by the Chinese government because of its known carcinogenicity. It has been estimated that 17 types of benzidine derived dyes had been produced in Shanghai, and their accumulated total was about 37000 tonnes between 1952 and 1975.

This study was conducted in seven factories producing benzidine derived dyes. Firstly, we ascer-
Table 3 Occupational classification for 41 cases of bladder cancer with a history of occupational exposure to benzidine

\begin{tabular}{lr}
\hline Classification & Cases $(\%)$ \\
\hline Dyestuffs & $23(56 \cdot 1)$ \\
Ink & $8(19 \cdot 5)$ \\
Rubber & $4(9 \cdot 8)$ \\
Dress pressing & $2(4 \cdot 9)$ \\
Cable & $1(2 \cdot 4)$ \\
Cigarette production & $3(7 \cdot 3)$ \\
Total & 41 \\
\hline
\end{tabular}

tained which workshops used benzidine by looking up the records that showed the types and outputs of the dyes produced, in every factory. Secondly, we obtained the names of all the subjects and their working years from the relevant workshops. Only those having an exposure of more than six months were accepted as subjects, including retired and transferred workers. Persons who had never been exposed to aromatic amines or other definite carcinogens were selected from the same factories as the control group. Data on personnel were obtained from the factory records by visiting the subjects or their family and relatives, and by communicating with retired subjects who had returned to their original home. The data set contained the date of birth, birthplace, time of transfer or retirement, history of smoking, the time of the first entry into the chemical industry or workshops using benzidine, the accumulated working time in the workshop, and date and cause of death.

Because there were different extents of exposure in different jobs, it was necessary to determine the nature of this. The manufacture of benzidine derived dyes may be divided into two parts, each of which includes several jobs. The parts were named the presynthesis process encompassing the chemical changes from benzidine to dyes, and the postsynthesis process, encompassing the physical processes leading to finished dyes (fig 1). The subjects were divided into presynthesis and postsynthesis groups. All those who had worked in material treatment (assignment, transport, and mixing), synthetic reaction (dissolution, diazotisation, coupling, or sulphuration), and others associated with jobs in the workshop (maintenance, technicians, analysts, and administrators) for more than six months were listed in the presynthesis group although some may have also worked in the postsynthesis process. The postsynthesis group included those subjects who had

Table 2 Analysis of relation of bladder cancer with history of occupational exposure and smoking

\begin{tabular}{|c|c|c|}
\hline Comparison & Statistical index & p Value \\
\hline $\begin{array}{l}\text { Significance test for relative risks of smoking and non-smoking with occupational exposure history } \\
\text { Significance test for the relative risks of having or not having occupational exposure history with smoking } \\
\text { Smoking with bladder cancer after adjustment for occupational exposures } \\
\text { Occupational exposure with bladder cancer after adjustment for smoking }\end{array}$ & $\begin{array}{l}\mathrm{U}=0.82 \\
\mathrm{U}=2 \cdot 96 \\
\chi^{2}=4 \cdot 22 \\
\chi^{2}=22 \cdot 39\end{array}$ & $\begin{array}{l}\text { NS } \\
<0.05 \\
<0.05 \\
<0.001\end{array}$ \\
\hline
\end{tabular}




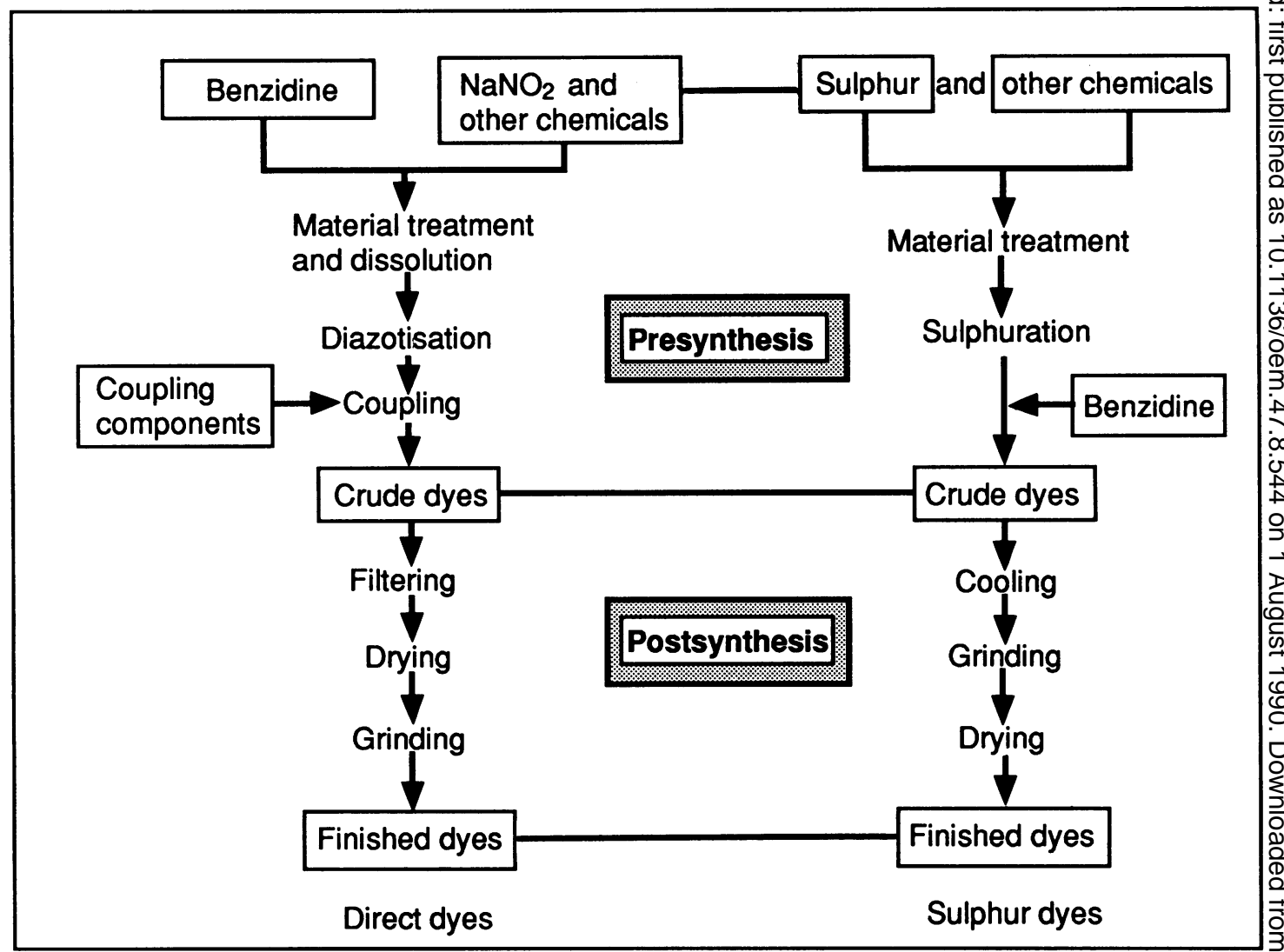

Figure 1 Technological process in manufacture of benzidine derived dyes.

worked in filtering, drying, grinding, and packing; never in the presynthesis process.

Home and hospital visits were made for subjects with malignant tumours or those who had died to establish the case history and to record the details of diagnosis and treatment. The observation period was from the first entry to the workshops or the chemical factories until the end of 1982 . The study was based on an exposed cohort of 550 men and 186 women, and a control group of 435 men and 121 women. The job grouping of the exposure cohort was made only among the men because of the small number of women; the presynthesis group contained 354 men, and the postsynthesis group, 196 men.

Forty eight cases of malignant tumour (15 cases of bladder cancer) occurred in the cohort of workers exposed to benzidine and 14 cases (no bladder cancer) were found in the control group. Of the 62 cases of cancer diagnosed, $58.1 \%$ (36 cases) had original pathological reports; in the remaining $41.9 \%$ (26 cases) the diagnosis was made from special examinations or after operation. All 15 cases of bladder cancer (14 men and one woman) had a pathological diagnosis, 14 had transitional cell car- cinoma, and the other had a deeply infiltrating tumour which could not be classified micro-? scopically.

Table 4 shows the results compared with the control group and standardised with the data for malignant tumours in the urban area population of Shanghai. Among the exposed group standardised incidence ratio (SIR) and standard mortality ratio (SMR) of bladder cancer were significantly highere. than that of the general population in Shanghai, and the RRs of bladder cancer and all cancers were also raised. Table 5 shows that the 14 cases of bladder cancer in men were all in the presynthesis group.w Table 5 also shows that the morbidity and mortality of bladder cancer in the presynthesis group were significantly higher than in the Shanghai urban area $\mathbb{D}$ The morbidity from all cancers in the presynthesis group was also significantly increased. Further analysis of data for the presynthesis group showed that the morbidity and mortality of bladder cancer? among workers engaged in jobs of material treatmento and synthetic reaction were significantly increased. The morbidity from all cancers was higher only in theo subgroup working on material treatment (table 6). 
'le 4 Morbidity, mortality, and RR of cancers estimated for exposed and control groups

\begin{tabular}{|c|c|c|c|c|c|c|c|c|c|c|c|c|}
\hline \multirow[b]{2}{*}{ iects } & \multirow[b]{2}{*}{$\begin{array}{l}\text { Sites of } \\
\text { cancer }\end{array}$} & \multicolumn{5}{|c|}{ Morbidity } & \multicolumn{5}{|c|}{ Mortality } & \multirow[b]{2}{*}{$R R \ddagger$} \\
\hline & & $\begin{array}{l}\text { Person- } \\
\text { years }\end{array}$ & $\begin{array}{l}\text { No of } \\
\text { cases }\end{array}$ & $C R \dagger$ & $S R+$ & $S I R$ & $\begin{array}{l}\text { Person- } \\
\text { years }\end{array}$ & $\begin{array}{l}\text { No of } \\
\text { cases }\end{array}$ & $C R \dagger$ & $S R \dagger$ & $S M R$ & \\
\hline \multicolumn{13}{|c|}{ Men } \\
\hline osed & $\begin{array}{l}\text { All cancers } \\
\text { Bladder } \\
\text { Digestive } \\
\text { Respiratory }\end{array}$ & 10744 & $\begin{array}{r}44 \\
14 \\
18 \\
9\end{array}$ & $\begin{array}{r}409 \cdot 63 \\
130 \cdot 31 \\
107 \cdot 54 \\
83 \cdot 77\end{array}$ & $\begin{array}{r}340 \cdot 76 \\
104 \cdot 67 \\
162 \cdot 75 \\
90 \cdot 04\end{array}$ & $\begin{array}{c}134 \\
1918^{\star \star} \\
92 \\
127\end{array}$ & 10845 & $\begin{array}{r}31 \\
5 \\
16 \\
8\end{array}$ & $\begin{array}{r}285 \cdot 61 \\
40 \cdot 67 \\
147 \cdot 71 \\
73 \cdot 71\end{array}$ & $\begin{array}{r}245 \cdot 53 \\
54 \cdot 43 \\
146 \cdot 74 \\
81 \cdot 35\end{array}$ & $\begin{array}{c}115 \\
1471^{\star \star} \\
92 \\
131\end{array}$ & $\begin{array}{l}3 \cdot 14^{\star \star \star} \\
\propto^{\star \star} \\
1 \cdot 92 \\
2 \cdot 57\end{array}$ \\
\hline trols & $\begin{array}{l}\text { All cancers } \\
\text { Bladder } \\
\text { Digestive } \\
\text { Respiratory }\end{array}$ & 9167 & $\begin{array}{r}12 \\
0 \\
8 \\
3\end{array}$ & $\begin{array}{c}130 \cdot 62 \\
0 \\
87 \cdot 08 \\
32 \cdot 65\end{array}$ & $\begin{array}{c}165 \cdot 30 \\
0 \\
129 \cdot 14 \\
56 \cdot 72\end{array}$ & $\begin{array}{r}65 \\
0 \\
73 \\
80\end{array}$ & 9214 & $\begin{array}{r}11 \\
0 \\
7 \\
3\end{array}$ & $\begin{array}{c}119 \cdot 83 \\
0 \\
75 \cdot 97 \\
32 \cdot 56\end{array}$ & $\begin{array}{c}162 \cdot 26 \\
0 \\
121 \cdot 22 \\
60 \cdot 86\end{array}$ & $\begin{array}{r}76 \\
0 \\
76 \\
98\end{array}$ & $\begin{array}{l}1.00 \\
1.00 \\
1.00 \\
1.00\end{array}$ \\
\hline \multicolumn{13}{|c|}{ Women } \\
\hline osed & $\begin{array}{l}\text { All cancers } \\
\text { Bladder } \\
\text { Digestive } \\
\text { Respiratory }\end{array}$ & 2757 & $\begin{array}{l}4 \\
1 \\
2 \\
0\end{array}$ & $\begin{array}{c}145 \cdot 09 \\
38 \cdot 27 \\
72 \cdot 54 \\
0\end{array}$ & $\begin{array}{c}200 \cdot 18 \\
115 \cdot 00 \\
132 \cdot 99 \\
0\end{array}$ & $\begin{array}{c}101 \\
500{ }^{\star} \\
161 \\
0\end{array}$ & 2768 & $\begin{array}{l}2 \\
0 \\
1 \\
0\end{array}$ & $\begin{array}{c}72 \cdot 25 \\
0 \\
36 \cdot 13 \\
0\end{array}$ & $\begin{array}{c}139 \cdot 30 \\
0 \\
74 \cdot 66 \\
0\end{array}$ & $\begin{array}{r}100 \\
0 \\
105 \\
0\end{array}$ & $\begin{array}{l}1.58 \\
\propto \\
1.50 \\
\propto\end{array}$ \\
\hline trols & $\begin{array}{l}\text { All cancers } \\
\text { Bladder } \\
\text { Digestive } \\
\text { Respiratory }\end{array}$ & 2178 & $\begin{array}{l}2 \\
0 \\
1 \\
0\end{array}$ & $\begin{array}{c}92 \cdot 04 \\
0 \\
46 \cdot 02 \\
0\end{array}$ & $\begin{array}{c}204 \cdot 15 \\
0 \\
143 \cdot 07 \\
0\end{array}$ & $\begin{array}{r}103 \\
0 \\
172 \\
0\end{array}$ & 2186 & $\begin{array}{l}1 \\
0 \\
1 \\
0\end{array}$ & $\begin{array}{c}45 \cdot 75 \\
0 \\
45 \cdot 75 \\
0\end{array}$ & $\begin{array}{c}150 \cdot 44 \\
0 \\
169 \cdot 22 \\
0\end{array}$ & $\begin{array}{r}108 \\
0 \\
238 \\
0\end{array}$ & $\begin{array}{l}1 \cdot 00 \\
1 \cdot 00 \\
1 \cdot 00 \\
1 \cdot 00\end{array}$ \\
\hline
\end{tabular}

$<0.05 ; \star \star \mathrm{p}<0.01 ; \star \star \star \mathrm{p}<0.001$

$\mathrm{R}=$ Crude rate; $\mathrm{SR}=$ rate standardised with the morbidity and mortality of cancers in urban area of Shanghai during 1972-9.' erived from the crude rate.

Several factors that could be confounding were examined. In the presynthesis and postsynthesis groups the average times worked in the industry for the non-benzidine exposure group (in workshops not using benzidine) were 16.66 (SE 0.83 ) and 16.37 $(1.01)$ years. The average ages of first entry into the workshops using benzidine were $31.62(1.05)$ for the presynthesis group and $33.63(1.64)$ for the postsynthesis group. The average time from first employment in the workshop to this investigation or to first diagnosis of cancer or dying of other causes was $19.01(0.73)$ years for the presynthesis and 17.70 $(0.85)$ years for the postsynthesis groups. There were no significant differences between the groups in these respects. Nor was any significant difference noted in the averge total cigarette consumption between the two groups. namely, that occupational factors played a more important part in development of bladder cancer than smoking-was more obvious in this study. Table 7 shows the RRs of bladder cancer with smoking and occupational factors. The RRs for bladder cancer among smokers of the presynthesis and the exposed groups were significantly higher than among smokers of the control group. Moreover, the RRs among the non-smokers of the presynthesis and the exposed groups were significantly higher than among the non-smokers of the control group.

The mean latent period of the 14 cases of bladder cancer was 20 years (range 3-30 years, mostly 20-29 years). The exposure time ranged from one to 16 years, mostly less than 10 years, and the average was eight. The age adjusted morbidity increased with exposure time (table 8). The ages at first diagnosis of bladder cancer ranged from 47 to 74 , and the

rable 5 Morbidity and mortality of cancers in presynthesis and postsynthesis groups of male producers of benzidine derived dyes

\begin{tabular}{|c|c|c|c|c|c|c|c|c|c|c|c|}
\hline \multirow[b]{2}{*}{ ¡ubjects } & \multirow[b]{2}{*}{$\begin{array}{l}\text { Sites of } \\
\text { cancer }\end{array}$} & \multicolumn{5}{|c|}{ Morbidity } & \multicolumn{5}{|c|}{ Mortality } \\
\hline & & $\begin{array}{l}\text { Person- } \\
\text { years }\end{array}$ & $\begin{array}{l}\text { No of } \\
\text { cases }\end{array}$ & $C R \dagger$ & $S R \dagger$ & $S I R$ & $\begin{array}{l}\text { Person- } \\
\text { years }\end{array}$ & $\begin{array}{l}\text { No of } \\
\text { cases }\end{array}$ & $C R \dagger$ & $S R \dagger$ & $S M R$ \\
\hline $\begin{array}{l}.54 \\
\text { resynthesis }\end{array}$ & $\begin{array}{l}\text { All cancers } \\
\text { Bladder } \\
\text { Digestive } \\
\text { Respiratory }\end{array}$ & 7067 & $\begin{array}{r}34 \\
14 \\
12 \\
5\end{array}$ & $\begin{array}{r}481 \cdot 11 \\
198 \cdot 11 \\
169 \cdot 80 \\
70 \cdot 75\end{array}$ & $\begin{array}{r}457 \cdot 68 \\
227.50 \\
185 \cdot 75 \\
90 \cdot 04\end{array}$ & $\begin{array}{l}178^{\star \star} \\
3500^{\star \star} \\
105 \\
127\end{array}$ & 7173 & $\begin{array}{r}22 \\
5 \\
10 \\
5\end{array}$ & $\begin{array}{r}306 \cdot 71 \\
69 \cdot 71 \\
139 \cdot 41 \\
69 \cdot 71\end{array}$ & $\begin{array}{r}296 \cdot 77 \\
115 \cdot 63 \\
156 \cdot 31 \\
90 \cdot 67\end{array}$ & $\begin{array}{c}139 \star \star \\
3125^{\star \star} \\
96 \\
146\end{array}$ \\
\hline $\begin{array}{l}96 \\
\text { ostsynthesis }\end{array}$ & $\begin{array}{l}\text { All cancers } \\
\text { Bladder } \\
\text { Digestive } \\
\text { Respiratory }\end{array}$ & 3677 & $\begin{array}{r}10 \\
0 \\
6 \\
4\end{array}$ & $\begin{array}{c}271 \cdot 96 \\
0 \\
163 \cdot 18 \\
108 \cdot 78\end{array}$ & $\begin{array}{c}165 \cdot 04 \\
0 \\
129 \cdot 14 \\
90 \cdot 75\end{array}$ & $\begin{array}{r}73 \\
0 \\
73 \\
128\end{array}$ & 3681 & $\begin{array}{l}9 \\
0 \\
6 \\
3\end{array}$ & $\begin{array}{c}244 \cdot 50 \\
0 \\
163 \cdot 00 \\
81 \cdot 50\end{array}$ & $\begin{array}{c}172.94 \\
0 \\
133.98 \\
69.55\end{array}$ & $\begin{array}{r}81 \\
0 \\
84 \\
112\end{array}$ \\
\hline
\end{tabular}

${ }^{\star} \mathrm{p}<0.01$

See table 4 for details. 
Table 6 Morbidity and mortality of cancers for job subsets of male presynthesis group

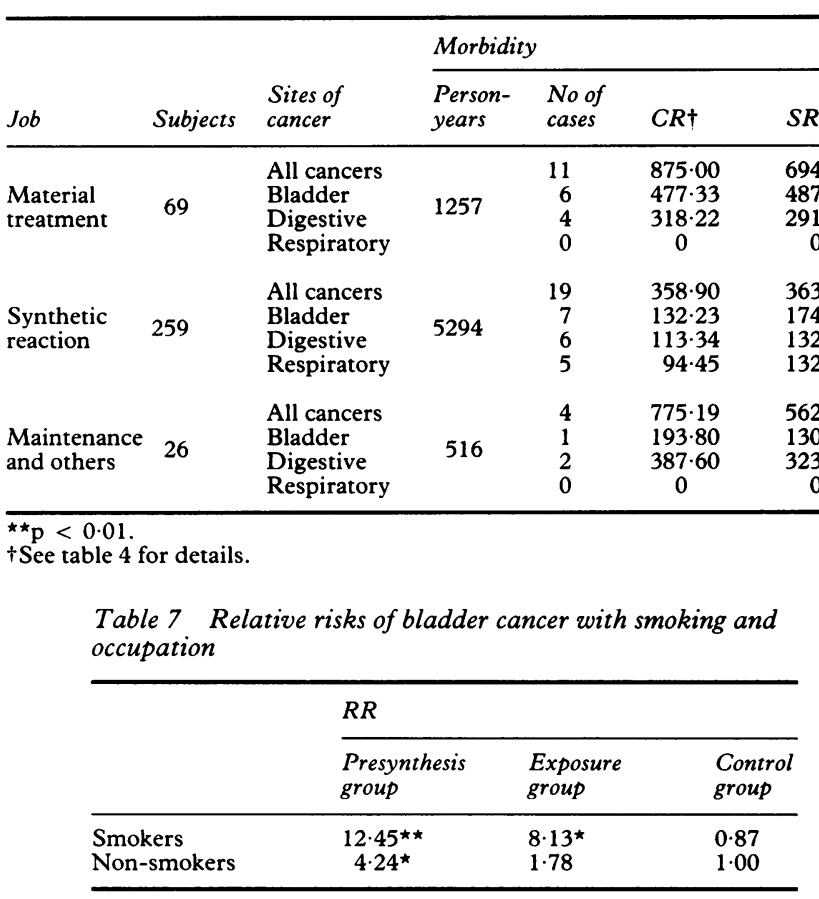

${ }^{\star} \mathrm{p}<0.05 ;{ }^{\star \star} \mathrm{p}<0.01$.

distribution was consistent with the expected distribution calculated from the data of the urban area of Shanghai (1972-9) (fig 2). The first case developed in 1964. There were three cases in the 1960 s and four in the 1970s. The other seven developed between 1980 and 1983, three in 1982. Of the 14 cases, four had recurred and five had died (five more cases have died since 1983). The survival period was from one to 16 years with a median survival period of seven years. Only one female case of bladder cancer occurred in 1980, and the age at the first diagnosis was 51 . The latent period was 11 years and the exposure time was 4.75 years. The woman has survived and the disease has not recurred.

After this study, a medical surveillance by urinary exfoliative cytology has been established (from 1982). Based on the average latent period mentioned above, examination of urinary sediment has been performed in 212 subjects, whose duration from the first entry into the workshops using benzidine was more than 20 years.

Table 9 shows some results of this screening. Eight subjects in the presynthesis group were in grades 3 or 4 ; no one in the postsynthesis group was beyond grade 2 . Two cases of bladder cancer developed in the presynthesis group during this period of surveillance; both cancers were suspected on urinary exfoliative cytology and before the appearance of haematuria.

RETROSPECTIVE COHORT STUDY INTO TEXTILE PRINTING AND DYEING INDUSTRY

This study was conducted in $17 \mathrm{knitting}$ factories, 100 stocking factories, nine silk printing and dyeing factories, and seven printing and dyeing factories in $\vec{\bullet}$ Shanghai. These factories were using or had used@ benzidine derived dyes. The jobs where the workers were exposed directly to the dust of these dyes wereo weighing, formulating, and dyeing.

The study group consisted of all those who hado worked in weighing and formulating or dyeing forô more than one year (comprising those who were still 2 active, retired, transferred, or who had died). These $\vec{\circ}$

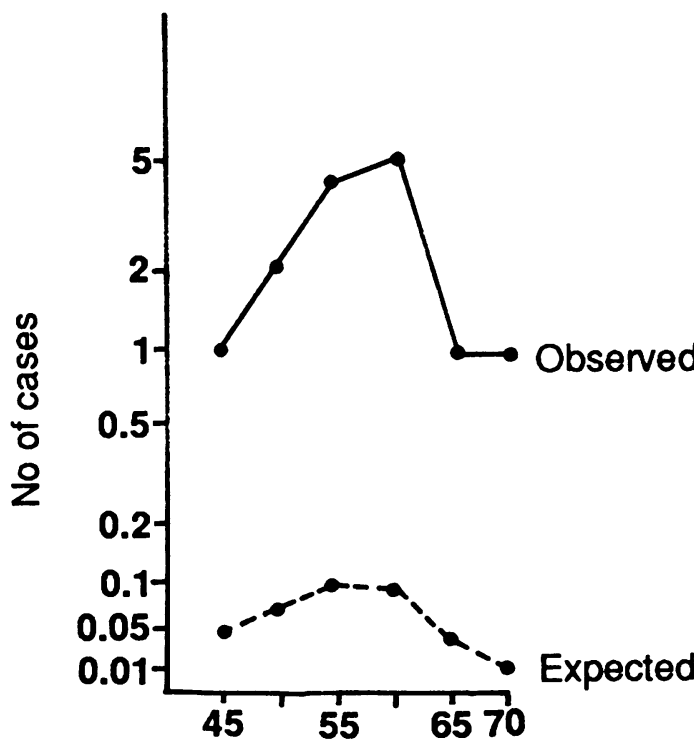

\section{Age at first diagnosis $(y)$}

Figure 2 Age distribution of 14 cases of bladder cancer in men in presynthesis group and expected distribution in urban area of Shanghai. 
Table 8 Relationship between time of exposure to benzidine and morbidity of bladder cancer in men

\begin{tabular}{lcccrr}
\hline Exposure time $(y)$ & No of subjects & Person-years & No of cases & CR $\dagger$ & $S R+$ \\
\hline $0 \cdot 5-4$ & 327 & 5541 & 6 & $180 \cdot 28$ & $120 \cdot 33$ \\
$5-9$ & 133 & 2870 & 2 & $69 \cdot 69$ & 65.00 \\
$10-14$ & 54 & 1360 & 3 & $220 \cdot 59$ & $195 \cdot 65$ \\
$15-19$ & 31 & 831 & 3 & 0 & 0 \\
$\geqslant 20$ & 5 & 1074 & 0 & $130 \cdot 31$ & 124.67 \\
Total & 550 & & 14 & & 124.67 \\
\hline
\end{tabular}

†See table 4 for details.

Table 9 Results of urinary cytological examination

\begin{tabular}{llllllll}
\hline & \multirow{8}{*}{$\begin{array}{l}\text { No of } \\
\text { subjects }\end{array}$} & 1 & $1-2$ & 2 & $2-3$ & 3 & $3-4$ \\
\cline { 3 - 8 } Group & 173 & 40 & 80 & 44 & 3 & 6 & 2 \\
\hline Presynthesis & 37 & 7 & 17 & 13 & 0 & 0 & 0 \\
\hline Postsynthesis & & & & & &
\end{tabular}

^Papanicolaou's classification.

subjects were divided into two groups, with high exposure ( $>500 \mathrm{~kg} \mathrm{a}$ month) and low exposure $(<500 \mathrm{~kg}$ a month). A control population was selected from each factory; it was close to the exposure groups in sex and age, and its members had never been exposed to dyes or other confirmed or suspected carcinogens. The method and the content of investigation were the same as the retrospective cohort study in the textile printing and dyeing industry and the period of observation was from 1949 to 1983 . The results were standardised with the data on cancer incidence during 1972-9 in Shanghai ${ }^{1}$ and comparisons were made between the groups.

In the Shanghai textile industry the use of benzidine derived dyes reached a peak in the 1950 s with the enlargement of the productive capacity of the industry. Since the 1960s, however, their use had gradually decreased with the development of new types of dye. Because of its known carcinogenicity the production and use of benzidine derived dyes have been strictly restricted for the last 15 years. Of the 43 factories involved in this study, 17 were still using these dyes, however, because of their better properties and lower price compared with alternatives. Fifteen types of benzidine derived dyes have been used in the 43 factories. The dyes used in largest quantity were direct black 38 (CI 30325), direct green (CI 30295), direct brown 95 (CI 30145), direct red 13 (CI 22155), direct brown 79 (CI 30050), and direct brown 1 (CI 30045); all are bis-azo dyes.

The exposure group consisted of 1210 workers (1060 men and 150 women) directly exposed to benzidine derived dyes; 18 men were lost to follow up. The control group comprised 411 persons (350 men and 61 women). Among men, the high exposure group comprised 496 subjects, and the low exposure group 546 subjects. Fifty eight cases of cancer occurred in the exposure group and 10 in the control group. All 68 cases were diagnosed by pathological or other special examination at hospital. In the exposure group, the sequence of different sites of cancer was stomach (21 cases), lung (15), liver (eight), oesophagus (six), and intestine (two). This was consistent with that in the Shanghai urban area. ${ }^{1}$ There was only one case of bladder cancer in the exposure group. Fifty five cases of cancer had died in the exposure group and six in the control group.

The morbidity and mortality of all cancers, digestive tract cancers, and respiratory tract cancers in the exposure group did not differ significantly after standardisation from those in the urban area of Shanghai (table 10). In the control group, however, the morbidity and mortality from all cancers and digestive tract cancers were significantly lower than in the urban area of Shanghai. Relative risks for all cancers (RR 1.97) and digestive tract cancers (RR 3.23) were significantly raised in the exposed group. No significant difference was shown in the morbidity and mortality of cancers between the high and the low exposure groups (table 11).

Comparing the different times of exposure in the

able 10 Morbidity and mortality for cancer in exposure and control groups

\begin{tabular}{|c|c|c|c|c|c|c|c|c|c|}
\hline \multirow[b]{2}{*}{ o of subjects } & \multirow[b]{2}{*}{ Sites } & \multicolumn{4}{|l|}{ Morbidity } & \multicolumn{4}{|l|}{ Mortality } \\
\hline & & Person-years & Cases & $S R \dagger$ & SIR & Person-years & Cases & $S R+$ & $S M R$ \\
\hline )42 exposure & $\begin{array}{l}\text { All cancers } \\
\text { Digestive } \\
\text { Respiratory }\end{array}$ & 23796 & $\begin{array}{l}58 \\
38 \\
16\end{array}$ & $\begin{array}{r}179.87 \\
135.61 \\
60.90\end{array}$ & $\begin{array}{l}71 \\
77 \\
86\end{array}$ & 23847 & $\begin{array}{l}55 \\
36 \\
15\end{array}$ & $\begin{array}{r}172.99 \\
133.04 \\
59 \cdot 11\end{array}$ & $\begin{array}{l}81 \\
83 \\
95\end{array}$ \\
\hline 350 control & $\begin{array}{l}\text { All cancers } \\
\text { Digestive } \\
\text { Respiratory }\end{array}$ & 8096 & $\begin{array}{r}10 \\
4 \\
3\end{array}$ & $\begin{array}{r}108 \cdot 49 \\
50 \cdot 83 \\
41 \cdot 46\end{array}$ & $\begin{array}{l}43^{\star \star} \\
29^{\star \star} \\
58\end{array}$ & 8108 & $\begin{array}{l}6 \\
2 \\
3\end{array}$ & $\begin{array}{r}108 \cdot 44 \\
26 \cdot 39 \\
45 \cdot 53\end{array}$ & $\begin{array}{l}31^{\star \star} \\
17^{\star \star} \\
70\end{array}$ \\
\hline
\end{tabular}

$\star \mathrm{p}<0.01$

See table 4 for details. 
Table 11 Morbidity and mortality of major cancers in both exposure groups

\begin{tabular}{|c|c|c|c|c|c|c|c|c|}
\hline \multirow[b]{2}{*}{ No of subjects } & \multirow[b]{2}{*}{ Sites } & \multicolumn{4}{|l|}{ Morbidity } & \multicolumn{3}{|l|}{ Mortality } \\
\hline & & Person-years $\dagger$ & Cases & $S R+$ & SIR† & Person-years $†$ & Cases & $S R \dagger$ \\
\hline 496 high exposure & $\begin{array}{l}\text { All cancers } \\
\text { Stomach } \\
\text { Lung } \\
\text { Liver } \\
\text { Oesophagus }\end{array}$ & 11301 & $\begin{array}{r}24 \\
12 \\
5 \\
3 \\
2\end{array}$ & $\begin{array}{r}161 \cdot 63 \\
81 \cdot 70 \\
35 \cdot 41 \\
17 \cdot 34 \\
14 \cdot 76\end{array}$ & $\begin{array}{r}64 \\
130 \\
68 \\
45 \\
59\end{array}$ & 11314 & $\begin{array}{r}23 \\
11 \\
5 \\
3 \\
2\end{array}$ & $\begin{array}{r}161 \cdot 32 \\
78 \cdot 32 \\
36 \cdot 35 \\
17 \cdot 42 \\
15 \cdot 28\end{array}$ \\
\hline 546 low exposure & $\begin{array}{l}\text { All cancers } \\
\text { Stomach } \\
\text { Lung } \\
\text { Liver } \\
\text { Oesophagus }\end{array}$ & 12495 & $\begin{array}{r}34 \\
9 \\
10 \\
5 \\
4\end{array}$ & $\begin{array}{r}190.82 \\
50.39 \\
57 \cdot 14 \\
25.39 \\
23.46\end{array}$ & $\begin{array}{r}75 \\
83 \\
109 \\
76 \\
93\end{array}$ & 12533 & $\begin{array}{r}32 \\
8 \\
9 \\
5 \\
4\end{array}$ & $\begin{array}{r}182 \cdot 33 \\
46 \cdot 07 \\
52 \cdot 03 \\
26 \cdot 71 \\
23 \cdot 71\end{array}$ \\
\hline
\end{tabular}

†See table 4 for details.

exposure group, no correlation was shown between cancer morbidity and exposure time $\left(\chi^{2}=4 \cdot 25\right.$, $\mathrm{p}>0.02$ ) (table 12).

\section{Discussion}

Bladder cancer is one of the common carcinomas, especially in men; the morbidity of bladder cancer in the world is between $2 \cdot 8$ and $22 \cdot 2 / 100000 .^{2}$ In the 1970 s the morbidity of bladder cancer was $7 \cdot 24$ / 100000 in Shanghai, and was the seventh most common carcinoma in men. ${ }^{1}$ That aromatic amines may exert carcinogenic effects on the bladder was first ascertained in 1895 for workers manufacturing dyes. ${ }^{3}$ Five aromatic amines which induce bladder cancer are listed ${ }^{4}$; benzidine is one and is a well known bladder carcinogen in man and in the dog. Besides occupational factors, a relation between smoking and bladder cancer has been noted. As the biggest city in China, Shanghai had developed various industries quite early, and the use of benzidine and its derived dyes had started in the 1930s and 1940s or even earlier, and lasted for more than 30 years. Here it was considered essential to study the correlation between bladder cancer and benzidine or its derived dyes, and to provide measures for preventing bladder cancer in Shanghai.

Bladder cancer is one of the common occupational cancers; in highly industrialised areas occupation may account for $25 \%$ of bladder cancer in men, ${ }^{5}$ and it was reported that $\mathbf{3 7}$ of $\mathbf{3 1 0}$ male cases of bladder cancer $(12 \%)$ had a history of more than five years of exposure to dyestuffs. ${ }^{6}$ In a study of the occupational history of 1030 cases of bladder cancer it was found

Table 12 Morbidity of cancers with time exposed to benzidine

\begin{tabular}{lllcl}
\hline $\begin{array}{l}\text { Time exposed to } \\
\text { benzidine }(y)\end{array}$ & $\begin{array}{l}\text { No of } \\
\text { subjects }\end{array}$ & $\begin{array}{l}\text { Person- } \\
\text { years }\end{array}$ & Cases & SR $\dagger$ \\
\hline $1-4$ & 245 & 2690 & 7 & 266.48 \\
$5-14$ & 380 & 8597 & 28 & 265.09 \\
$15-24$ & 237 & 6593 & 12 & 118.92 \\
$\geqslant 25$ & 180 & 5915 & 11 & 116.94 \\
\hline
\end{tabular}

† See table 4 for details that more than $20 \%$ had worked in factories producir ing dyestuffs. ${ }^{7}$ Also, $17(8.5 \%)$ of 200 cases of bladder $\vec{A}$ cancer in men were employed as dyeing workers. ${ }^{8}$ In our case-control study $12.9 \%(41 / 317)$ had a historyof positive occupational exposures to dyes, which approximates to the levels given in other reports. 을

So far as exposure to dyestuffs is concerned, as one? may be exposed not only to the different types of dye but to the different intermediates of dyestuff, ours case-control study could not determine the specific chemicals to which exposure occurred or the causeo specific morbidity. It could give some clues to severa aetiologies, and the conclusions may be ambiguous in defining associations.

In the retrospective cohort study the subjects were explored from cause to result. Although it was $\vec{B}$ possible that the cohort members had been exposed $\mathrm{B}$ to other chemicals, it was certain that they had all had exposure to benzidine or its derived dyes; thus cause analysis was possible. The incidence of bladdero cancer was higher among those working with ben- 3 zidine, and the incidence of morbidity from allo cancers was also increased compared with controls There are large differences in reported incidence of bladder cancer in people exposed to benzidine; the ${ }^{3}$ incidence among the workers manufacturing ben-응 zidine may reach $19 \cdot 1 \%$ whereas among the users it was only $2.9 \%{ }^{910}$ In our study a similar incidence of? bladder cancer of $2 \cdot 55 \%(14 / 550)$ was found in the men. The latent period and the exposure time were ${ }^{\circ}$ also consistent with previous studies. ${ }^{511}$ A dose 0 response relation existed between exposure time and N the morbidity of bladder cancer. Thus this study haso confirmed that the bladder cancer that developed in workers exposed to benzidine is an occupational ${ }_{\mathscr{\Phi}}^{-}$ cancer in the Shanghai dyestuffs industry.

In the retrospective cohort study there were not data on the benzidine concentrations in the presynthesis or postsynthesis process because the manufacture of benzidine derived dyes had been $\vec{\Phi}$ stopped for many years in China. These two proces- -0 ses, however, were usually placed on separate floors in Shanghai dyestuffs factories and as those who hado 
worked in both processes were assigned to the presynthesis group the 196 men in the postsynthesis group were all exposed to dyes rather than benzidine itself. Therefore, the results in this study suggested different degrees of carcinogenicity between benzidine and its derived dyes.

Since the 1970s concern has been expressed as to whether dyes containing the unsubstituted benzidine moiety have a carcinogenicity similar to that of benzidine itself. Until now, however, no conclusions have been drawn because of lack of information from cohort studies. Kingsley mentioned in his review in 1977 that an excess of lung cancer was found in some studies among printers, newspaper workers, and typographers in the United Kingdom, but in the United States printers did not show a higher than normal incidence of cancers in several investigations. ${ }^{12}$ Two studies conducted in England did not suggest an excess of bladder cancer.

Kingsley also pointed out that studies on cancer incidence among textile printing, dyeing, and finishing personnel of the industries appeared not to have been carried out. ${ }^{12}$ Nineteen epidemiological reports were published during 1958-78, concerning.textile, leather, plastics, paper manufacturing, shoe making and repairing industries, and Japanese kimono painters. The results showed large differences and positive associations were seen mainly in the leather industry. ${ }^{13}$ It was unfortunate that these reports were all case-control studies as the investigation of occupational history could only reach the level of "working with dyestuffs." It was difficult to ascertain which dyes the cases were exposed to, and what part the benzidine derived dyes played. A review published in 1984 mentioned that only two epidemiological studies suggested that dyes derived from benzidine may induce cancers in man. ${ }^{14}$ One was a case-control study of bladder cancer in which four types of dyes were involved. The other showed an excess of bladder cancer among some workers in drying and grinding processes in the dyestuffs industry, and the detection of benzidine in the urine of these workers. The evidence for carcinogenicity of benzidine derived dyes, therefore, did not seem as conclusive as that for benzidine itself. More definite information is required urgently, however, because these dyes are used widely. In addition to the printing and dyeing, leather tanning, paper, printing, ink, plastic, and arts and crafts industries, they have been used in the production of cosmetics and hair dyes. About 150000 workers were potentially exposed in the dyestuff manufacturing, textile dyeing, printing, paper, leather, and other 28 industries (not including arts and crafts) during 1972-4 in the United States. ${ }^{15}$ Compared with this, the population exposed to benzidine (including manufacturing and using) is much smaller. Based on our data, the number of workers actually exposed to benzidine in the pre- synthesis group was only 413, whereas 1210 workers were exposed to dyes in the textile printing and dyeing factories. Also, it is estimated that more than 2000 workers are exposed to these dyes in the leather tanning industry in Shanghai. It is necessary to evaluate how much potential risk of cancer is faced by such a large number of workers.

In our study the 15 cases of bladder cancer were all in the presynthesis group, and the highest incidence occurred in the job of material treatment where there was direct exposure to benzidine. No case was seen in the postsynthesis group, members of which were exposed only to the dyes derived from benzidine. This finding has not been reported previously. Confirmation for this result was obtained from the study in the textile printing and dyeing factories.

Three types of benzidine derived dyes-namely, direct black 38, direct blue 6, and direct brown 95induced liver cancer in rats. ${ }^{16}$ Experiments on animals (rats, mice, dogs, and monkeys) demonstrated that these dyes may be reduced to benzidine in vivo as benzidine and acetylbenzidine were detected in urine after administration of dyes. ${ }^{17}$

The development of the Ames test led to the possibility of detecting the mutagenicity of benzidine derived dyes. We modified established protocols ${ }^{18} 19$ to satisfy the conditions in China, and used them for testing 12 different dyes used widely in China; all expressed mutagenicity. ${ }^{20}$

The metabolism of benzidine derived dyes in the body is related directly to their carcinogenicity. It was assumed that after entering the body these dyes were reduced and their azo bonds cleaved by anaerobic bacteria in the gut to release benzidine, which was then transferred to the liver and further metabolised enzymatically by $\mathrm{N}$-hydroxylation into the ultimate carcinogen. ${ }^{21}$ Thus the reductive cleavage of azo bonds is thought to be the key to the dyes' carcinogenic properties. Many studies have shown that in vivo and in vitro micro-organisms can cleave the azo bond of some benzidine derived dyesfor instance, direct black 38, to release benzidine itself. $^{22-24}$

The intestinal metabolism of these dyes in man is likely to be a complex process. It is thought that the reductive process requires an activated enzyme system and the appropriate micro-organisms to be present simultaneously, so that the free amines are further metabolised immediately and could attack the target cells directly. ${ }^{21}$ In man, the process occurs in the intestine, liver, and bladder. These dyes are always difficult to fully reduce, and the rates of benzidine and monoacetylbenzidine collected in urine are about $1.5 \%$ of the amount of benzidine in the dye molecules. ${ }^{14}$ Therefore, results from animal experiments and short time tests cannot be simply extrapolated to man.

The studies presented in this paper give the first 
epidemiological information concerning the effects of job difference on the incidence of bladder cancer in those manufacturing benzidine derived dyes, and the first report of a cohort study about cancer experience among the users of these dyes. The results suggest that the risk of bladder cancer exists mainly in the presynthesis process of dye manufacture and the benzidine derived dyes do not appear to be as strongly carcinogenic as benzidine. This supports a study that compared cases of bladder cancer in those exposed to benzidine with those working in the dye industry. ${ }^{25}$ It is too early to make firm conclusions based on our results; however, it is necessary to conduct cohort studies in various industries where these dyes are used, and more experiments on their metabolism; such studies are now in progress.

1 Department of Epidemiology, Shanghai Cancer Institute, et al. Analysis of cancer incidence, mortality, and survival rates in Shanghai urban area during the period of 1972-1979. Tumor 1982;2:385-91. (In Chinese.)

2 Waterhouse J, Muir C, Correa P, Poweu J. Cancer incidence in five continents. Vol III. Lyon: International Agency for Research on Cancer, 1976. (IARC sci publ No 15.)

3 Haley TJ. Benzidine revisited: a review of the literature and problem associated with the use of benzidine and its congeners. Clin Toxicol 1975;8:13-42.

4 International Agency for Research on Cancer. Monographs, suppl 1. Chemicals and industrial process associated with cancer in humans. Vols 1-12. Lyon: IARC, 1979.

5 Sakari T, Marita T, Marja-Liise K, Erkki J. Cancer of the urinary in Finland association. Int Arch Occup Environ Health 1960;46:43-51.

6 Wynder E, Onderdonk J, Mantel N. An epidemiological investigation of cancer of the bladder. Cancer 1963;16:1388-407.

7 Anthony HM, Thomas KM. Tumors of the urinary bladder: an analysis of 1030 patients in Leeds, England. $J$ Natl Cancer Inst 1970;45:879-95.

8 Yoshida O, Harada TM. Bladder cancer in workers of dyeing industry. Igaku no Ayumi 1971;79:421-2. (In Japanese.)

9 Scott TS. The incidence of bladder tumours in a dyestuff factory. Br J Ind Med 1952;9:127-32.

10 Ishizu SK. Administration of occupational bladder cancer with urinary cytological diagnosis. Tokyo: Chemical Industrial Co, 1975:5-13.

11 Ishikawa $\mathrm{T}$, the Japanese research group of bladder carcinoma. Clinical application of 2,5 -di-acetyl- $\beta$-glucaro $(1-4)(6-3)$ dilactone (SIA) to the bladder tumor, with special reference to its effect on frequency of tumor recurrence. J Urol 1972; 108:571-6.

12 Kinsley MA. Potential cancer risk in the graphic arts and textile industries. In: Nieburgs HE, ed. Prevention and detection of cancer. Part I. Prevention, Vol I. Etiology. New York and Basel:D Marcel Dekker Inc, 1977:857-99.

13 Boeniger M. Carcinogenicity and metabolism of azo dyes, $\frac{\Phi}{\vec{D}}$ especially those derived from benzidine. Cincinnati: National Institute for Occupational Safety and Health, 1980:16-99.

14 Arthur RG. The carcinogenic potential of benzidine-based dyes. ڤొ J Environ Pathol Toxicol Oncol 1984;5:243-59.

15 DHEW. National occupational hazard survey-survey analysis. and supplemental tables. Cincinnati: US Dept of Health, $\vec{\overrightarrow{ }}$ Education and Welfare, Public Health Service, Center for $\vec{\omega}$ Disease Control, National Institute for Occupational Safetyo and Health, 1977. (DHEW (NIOSH) publ No 78-114.)

16 DHEW. 13-week subchronic toxicity studies of direct blue 6, direct $\mathbb{D}$ black 38, and direct brown 95 dyes. Cincinnati: US Dept of? Health, Education and Welfare, Public Health Service, \pm National Cancer Institute, Division of Cancer Cause and. Prevention, Carcinogenesis Testing Program, 1978:1-127. $\infty$ (DHEW publ No (NIH) 78-1358.)

17 Genin VA. Formation of blastomogenic diphenylamine $\vec{A}$ derivatives as a result of the metabolism of direct azo dyes. Voprosy Onkologii 1977;23:50-2. (In Russian.)

18 Sugimura $T$, Nagao $T$, Kawachi $M$, et al. Mutagen-carcinogens in food, with special reference to highly mutagenic pyrolytic products in boiled foods. In: Hiatt $\mathrm{HH}$, ed. Origins of human cancer. Book C. New York: Cold Spring Harbor Laboratory, 1977:1561-77.

19 Prival MJ, Valerie PM. Analysis of a method for testing azo dyes for mutagenic activity in salmonella typhimurium in the $\vec{\theta}$ presence of flavin mononucleotide and hamster liver $S_{9}$. Mutat Res 1982;97:103-16.

20 You Xue-yun, Zhou Yong-gui, Ye Xin-liang. Study on the method of the mutagenicity test for benzidine and itso derivatives. Chinese Journal of Industrial Hygiene and Occupational Disease 1987;5:146-59. (In Chinese.)

21 Thomas MR, Kenneth CM, Ching YW, Charles MK.O Conversion of Congo red and 2-azoxyfluorese to mutagens following in vitro reduction by whole-cell rat cecal bacteria. $\mathbb{Q}$ Mutat Res 1983;117:105-12.

22 Dieckhues $B$. Experiments on the reductive splitting of azo dyes $\overrightarrow{\vec{B}}$ by bacteria. Zentralblatt fur Bakteriologie, Parasittenkunde 3 infektionskrankheiten und Hygiene 1961;180:244-54. (InGerman.)

23 Yoshida O, Miyakawa M, Okada H. Reducing direct black EX, aO benzidine-derived dye, by colibacillus and bacteria from the soil. Igaku to Sebutsugaku 1973;86:361-4. (In Japanese.)

24 Miyakawa M, Harada T, Yoshida O. Reducing of direct black EX, a benzidine-derived dye, in the intestine of rats and mice. Igaku to Sebutsugaku 1973;86:355-60. (In Japanese.)

25 Ishizu S. Bladder cancer in the dyeing workers. Japanese Journal of Industrial Health 1983;25:650-6. (In Japanese.)

Accepted 17 July 1989 